\title{
Lactobacillus paucivorans sp. nov., isolated from a brewery environment
}

Correspondence

Matthias A. Ehrmann

M.Ehrmann@wzw.tum.de

\author{
Matthias A. Ehrmann, ${ }^{1}$ Patrick Preissler, ${ }^{1}$ Markus Danne ${ }^{2}$ \\ and Rudi F. Vogel ${ }^{1}$
}

${ }^{1}$ Lehrstuhl für Technische Mikrobiologie, Technische Universität München, Weihenstephaner Steig 16, 85350 Freising, Germany

${ }^{2}$ Brauerei C. \& A. Veltins GmbH \& Co. KG, An der Streue, 59872 Meschede-Grevenstein, Germany

\begin{abstract}
A Gram-stain-positive, catalase-negative and rod-shaped bacterium was isolated from a brewery environment. Its phylogenetic affiliation was determined by using 16S rRNA gene sequence analysis. It was found that strain TMW $1.1424^{\top}$ belongs to the genus Lactobacillus, with the three nearest neighbours Lactobacillus parabrevis LMG $11984^{\top}$ (97\%), Lactobacillus brevis DSM $20054^{\top}(95.9 \%)$ and Lactobacillus hammesii DSM $16381^{\top}$ (96.2\%). Comparative sequencing of additional phylogenetic marker genes tuf and pheS confirmed the 16S rRNA gene sequence tree topology. The DNA G $+\mathrm{C}$ content of strain TMW $1.1424^{\top}$ is $46.6 \mathrm{~mol} \%$. Genomic DNADNA relatedness values with $L$. brevis DSM $20054^{\top}$, L. parabrevis LMG $11984^{\top}$ and $L$. hammesii DSM $16381^{\top}$ do not exceed $52.8 \%$, revealing that the novel isolate represents a separate genomic species. The strain can be distinguished from other related species of the genus Lactobacillus by physiological and biochemical tests. Based on biochemical, physiological and phylogenetic data, it is proposed that the new isolate be classified as a novel species of the genus Lactobacillus, Lactobacillus paucivorans sp. nov. The type strain is TMW $1.1424^{\top}$ (=DSM

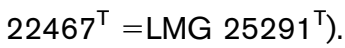

The genus Lactobacillus represents a large group within the Gram-positive bacteria with over 140 species with validly described names at the time of writing. The high diversity and species number results from association with a wide range of different environments. Lactobacilli can be found on plants, associated with humans or animals or in manmade habitats such as food and feed fermentations. Typically, these ecological niches are rich in nutrients, enabling high growth rates for many species that may be regarded as generalists. Other such niches are characterized by clearly defined conditions selective for only a few highly adapted species.

A unique environment for a small number of specialized species of the genus Lactobacillus is found in breweries. Besides raw materials and process equipment, they even occur in storage tanks as well as in the finished product, where growth conditions are limited by low oxygen

The GenBank/EMBL/DDBJ accession numbers for the partial $16 \mathrm{~S}$ rRNA, tuf and pheS gene sequences of strain TMW $1.1424^{\top}$ are FN185731-FN185733, respectively. The accession numbers for the tuf gene sequences of Lactobacillus parabrevis $11948^{\top}$, L. hammesii LMG $23074^{\top}$, L. nantensis DSM $16982^{\top}$ and L. crustorum LMG $23699^{\top}$ are FN395008-FN395011, respectively.

Maximum-likelihood and maximum-parsimony trees derived from $16 \mathrm{~S}$ rRNA gene sequence analysis are available with the online version of this paper. content, low $\mathrm{pH}$ and antibacterial effects of hop bitter acids and alcohol (Back, 2005; Suzuki et al., 2006). Known species with significant beer-spoilage ability include Lactobacillus brevis, Lactobacillus lindneri, Lactobacillus paracollinoides and Pediococcus damnosus. Less common beer-spoiling bacteria are Lactobacillus buchneri, L. casei, L. coryniformis, L. curvatus and L. plantarum (Priest, 1996). Recently, few newly discovered species of beer-associated lactobacilli have been described. An obligate beer-spoiling species, 'Lactobacillus backi', was typically found in lager, pils and wheat beers (Bohak et al., 2006). The brewery environment offers niches allowing for adaptation of lactic acid bacteria to grow in beer (Behr \& Vogel, 2009). During routine hygiene monitoring, we isolated a strain that was not allocable to any known species. In this study, we report on the taxonomy of the novel strain isolated from a storage tank. The isolate is designated strain TMW $1.1424^{\mathrm{T}}$.

For enrichment and isolation of strain TMW $1.1424^{\mathrm{T}}$ we used 3-fold concentrated MRS-broth (Oxoid CM359) supplemented with $30 \mathrm{~g}$ D-fructose $\mathrm{l}^{-1}$ and $1.5 \mathrm{~g}$ L-cysteine hydrochloride monohydrate $1^{-1}$. Pure cultures were routinely grown in modified MRS medium (mMRS) composed of $10 \mathrm{~g}$ tryptone $1^{-1}, 2 \mathrm{~g}$ meat extract $1^{-1}, 7 \mathrm{~g}$ yeast extract $1^{-1}, 10 \mathrm{~g}$ fructose $1^{-1}, 10 \mathrm{~g}$ xylose $1^{-1}, 2 \mathrm{~g}$ sodium gluconate $1^{-1}, 5 \mathrm{~g}$ sodium acetate trihydrate $1^{-1}, 2 \mathrm{~g}$ citric

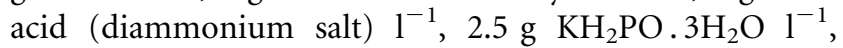


$0.2 \mathrm{~g} \mathrm{MgSO}_{4} \cdot 7 \mathrm{H}_{2} \mathrm{O} \mathrm{l}{ }^{-1}, 0.1 \mathrm{~g} \mathrm{MnSO}_{4} \cdot 4 \mathrm{H}_{2} \mathrm{O} \mathrm{l}{ }^{-1}, 0.5 \mathrm{~g}$ cysteine hydrochloride $\mathrm{l}^{-1}, 0.05 \mathrm{~g} \mathrm{FeSO}_{4} \cdot \mathrm{H}_{2} \mathrm{O} \mathrm{l}^{-1}$ and $1 \mathrm{~g}$ Tween $80 \mathrm{l}^{-1}$. The $\mathrm{pH}$ was adjusted to 5.4. Solid media contained agar $\left(15 \mathrm{~g} \mathrm{l}^{-1}\right)$.

Cell morphology and Gram staining of one- to two-dayold broth cultures of strain TMW $1.1428^{\mathrm{T}}$ were examined by phase-contrast and normal light microscopy, respectively, at $\times 1200$ magnification. Cells were Gram-stainpositive, short, straight rods and sometimes slightly curved, occurring singly, in pairs or in short chains. Opaque colonies of varying size appeared in two forms: circular, convex and smooth edged, or roughly textured with fringed edges.

\section{Physiology}

Catalase activity was tested by addition of $8 \mathrm{M} \mathrm{H}_{2} \mathrm{O}_{2}$ to cells. Lack of bubble formation indicated that strain TMW $1.1428^{\mathrm{T}}$ is catalase-negative. Ability to grow at different temperatures $\left(15,30,37\right.$ and $\left.45{ }^{\circ} \mathrm{C}\right)$ was determined in mMRS broth incubated under anaerobic atmosphere without agitation. Optimal growth was observed at $30{ }^{\circ} \mathrm{C}$. To investigate the effect of $\mathrm{NaCl}$ on bacterial growth, cells were inoculated at $30{ }^{\circ} \mathrm{C}$ in mMRS broth supplemented with 4, 6, 8 and $10 \%(\mathrm{w} / \mathrm{v}) \mathrm{NaCl}$ in anaerobic atmosphere. Growth at $8 \% \mathrm{NaCl}$ was one quarter of growth at $5 \%$ $\mathrm{NaCl}$, and almost no growth was observed at $10 \% \mathrm{NaCl}$. $\mathrm{NH}_{3}$ production from arginine was not observed when determined as described by Bover-Cid \& Holzapfel (1999). L-Ornithine and L-lysine were decarboxylated.

To discriminate homofermentative from heterofermentative pathway gas production from glucose, fructose, gluconate and xylose $\left(20 \mathrm{~g} \mathrm{l}^{-1}\right)$, mMRS broth with Durham tubes was used. Glucose was generally not fermented by strain TMW $1.1424^{\mathrm{T}}$. Fructose and xylose were fermented without gas production. Gluconate was not fermented.

The enantiomer of the lactic acid produced was determined enzymically (Boehringer Mannheim). D-Lactic acid and Llactic acid are produced in a ratio of $4: 1$.

Carbohydrate fermentation of additional sugars was determined by using API 50 CHL strips with API 50 CHL medium (bioMérieux). Strain TMW $1.1424^{\mathrm{T}}$ produced acid solely from D-fructose, D-ribose and D-xylose. Characteristics that differentiate strain TMW $1.1424^{\mathrm{T}}$ from other members of the $L$. brevis clade of lactobacilli are summarized in Table 1.

Fructose was simultaneously used as carbon source as well as electron acceptor to produce mannitol. Mannitol formation was detected by HPLC using a Metacarb 87P column (Varian) with a refractive index detector as described by Korakli et al. (2000).

Resistance to isomerized hop extract is considered as a pivotal feature of beer-spoiling lactic acid bacteria (Simpson \& Fernandez, 1992). As strain TMW $1.1424^{\mathrm{T}}$ was isolated
Table 1. Physiological characteristics of the novel strain TMW $1.1424^{\top}$ useful in differentiating it from its nearest phylogenetic relatives

Strains: 1 , L. paucivorans sp. nov. TMW $1.1424^{\mathrm{T}} ; 2$, L. brevis DSM $20054^{\mathrm{T}}$ (data from Valcheva et al., 2005); 3, L. parabrevis LMG $11984^{\mathrm{T}}$ (Vancanneyt et al., 2006); 4, L. hammesii DSM $16381^{\mathrm{T}}$ (Valcheva et al., 2005). All strains were negative for acid production from Dmannose, cellobiose, trehalose, raffinose and sucrose. All strains were positive for acid production from D-ribose. +, Positive; -, negative; w, weakly positive.

\begin{tabular}{|lcccc|}
\hline Characteristic & $\mathbf{1}$ & $\mathbf{2}$ & $\mathbf{3}$ & $\mathbf{4}$ \\
\hline Acid produced from: & & & & \\
$\quad$ L-Arabinose & - & + & + & + \\
Maltose & - & + & + & + \\
D-Fructose & + & + & + & + \\
Melibiose & - & + & - & - \\
Gluconate & - & + & + & $\mathrm{W}$ \\
D-Xylose & + & - & + & + \\
Hydrolysis of aesculin & - & - & - & + \\
DNA G+C content (mol \%) & 46.6 & 46 & 49 & 52.6 \\
\hline
\end{tabular}

from beer, its hop tolerance was evaluated by determining minimum inhibitory concentrations (MIC) of hop iso- $\alpha-$ acid as previously described (Behr \& Vogel, 2009). Briefly, cells were precultured in modified MRS broth ( $\mathrm{pH} 4.3$ ) with reduced manganese $\left(0.16 \mathrm{mg} \mathrm{l}^{-1}\right)$ and magnesium (98 $\mathrm{mg} \mathrm{l}^{-1}$ ) content at $30{ }^{\circ} \mathrm{C}$ for 4 days. Neither glucose nor cysteine were added.

The MIC test was performed in a 96-well microtitre plate. Five $\mu$ l precultured cells $\left(\mathrm{OD}_{590}\right.$ of 2$)$ were used to inoculate the test volume of $200 \mu$ l. The concentration of iso- $\alpha$-acid was increased gradually from 5 p.p.m. up to a concentration of 35 p.p.m. All experiments were performed in duplicate. After $48 \mathrm{~h}$ at $30{ }^{\circ} \mathrm{C}$, visible growth was detectable only at 5 p.p.m. hop iso- $\alpha$-acid (data not shown). This indicates a rather low beer-spoilage potential as compared to obligate beer-spoiling strains of $L$. brevis that are able to tolerate up to 11.6 p.p.m. (Behr \& Vogel, 2009).

\section{Metabolic activity in beer}

Stationary phase cells were washed twice with $50 \mathrm{mM}$ phosphate buffer ( $\mathrm{pH}$ 6.8) and dissolved to an $\mathrm{OD}_{590}$ of 2 in beer (pilsner). Five microlitres of the cell suspension was mixed with $200 \mu \mathrm{l}$ beer in a 96-well microtitre plate and overlaid with $100 \mu$ paraffin oil. L. brevis TMW 1.313 (high spoilage potential) and TMW 1.6 (no spoilage potential) served as positive and negative controls, respectively. Active metabolism was monitored after incubation for $48 \mathrm{~h}$ at $30{ }^{\circ} \mathrm{C}$ by addition of $10 \mu \mathrm{l}$ resazurin $(0.01 \mathrm{mM}$ in $500 \mathrm{mM}$ Tris, $\mathrm{pH} \mathrm{8.8)}$ as indicator. After one hour of incubation, change of absorbance (decoloration of resazurin) was measured spectrophotometrically at $590 \mathrm{~nm}$ by using a Tecan plate reader. No activity was detected for strain TMW $1.1424^{\mathrm{T}}$. 
Hop tolerance of beer-spoiling lactic acid bacteria is suggested to be a multi-gene trait (Fujii et al., 2005). Thus, several genetic markers differentiating beer-spoilage ability were established. The hor $A$ and hor $C$ genes encoding multidrug transporters (Sakamoto et al., 2001; Iijima et al., 2006), as well as hitA encoding a divalent cation transporter (Hayashi et al., 2001), have been reported to correlate strongly with hop tolerance.

A PCR screening with primers specific for horA (for: $5^{\prime}$ ATGCAAGCTCAGTCCAA-3'; rev: 5' -TCACCCGTTGCTCGTCGC-3') and horC (for: 5'-ATGTTCGATGTAATTCGT-3'; rev: 5'-TTATTTAATTTTGCGGTG-3') verified the presence of both genes, whereas hitA (for: $5^{\prime}$ ATGAAAGAGGGTATTGAT-3'; rev: 5'-TTAACCAATCACGCCAAC-3') was not detected.

\section{Phylogeny}

The phylogenetic position of strain TMW $1.1424^{\mathrm{T}}$ was determined by comparative sequencing of three phylogenetic marker genes (16S rRNA gene, tuf gene for elongation factor $\mathrm{Tu}$ and pheS gene for phenylalanyl-tRNA synthase alpha subunit). DNA was isolated with an E.N.Z.A. bacterial DNA kit (Omega Bio-Tek) according to the manufacturer's instructions. The complete 16S rRNA gene was amplified with primers 616V (5'-AGAGTTTGATYMTGGCTCAG-3' and 630R (5'-CAKAAAGGAGGTGATCC$\left.3^{\prime}\right)$. PCR products were purified by using the QIAquick PCR purification kit (Qiagen) and were eluted with $60 \mu \mathrm{l}$ elution buffer. DNA sequences were determined by the chain-termination method using the ABI Prism Dye Terminator Cycle Sequencing kit. The almost complete $16 \mathrm{~S}$ rRNA gene sequence of $1513 \mathrm{bp}$ (EMBL accession number FN185731) was compared with those of the most closely related species retrieved from GenBank. Levels of sequence similarity were found to be $97 \%$ with Lactobacillus parabrevis LMG $11984^{\mathrm{T}}$, $95.9 \%$ with L. brevis DSM $20054^{\mathrm{T}}$ and $96.2 \%$ with Lactobacillus hammesii DSM $16381^{\mathrm{T}}$. A $16 \mathrm{~S}$ rRNA gene sequence similarity lower than $98.7 \%$ has been determined sufficient evidence that organisms belong to different species (Stackebrandt \& Ebers, 2006).

A phylogenetic tree on the basis of a multiple alignmentbased similarity matrix was reconstructed by the neighbour-joining method (Saitou \& Nei, 1987) using the software package Bionumerics (Applied Maths). Unknown bases were discarded from the analyses. Bootstrapping analysis was undertaken to test the statistical reliability of the topology of the neighbour-joining tree by using 100 bootstrap resamplings of the data (Fig. 1).

Additional neighbour-joining trees were reconstructed with $t u f$ and pheS gene sequences (Fig. 2). The tuf gene is highly conserved in the bacterial genome. The amino acid sequence of this gene differs by no more than $27 \%$ between even the most divergent eubacterial species (Lathe \& Bork, 2001). For sequence analysis, tuf was partly (1041 bp) amplified with oligonucleotides complementary to conserved regions of other bacterial tuf genes. The forward primer was $5^{\prime}$-CCAYGWAAAYATYGGTAC- $3^{\prime}$ and the reverse primer was $5^{\prime}$-GTTRTCRCCAGGCATAAC-3'. Annealing temperature was optimal at $56{ }^{\circ} \mathrm{C}$. A $965 \mathrm{bp}$ region was successfully sequenced (EMBL accession number FN185732). Sequence comparison revealed similarities of $94 \%$ to $L$. hammesii DSM $16381^{\mathrm{T}}$ and $92 \%$ to $L$. parabrevis LMG $11984^{\mathrm{T}}$.

In addition to sequencing of the tuf gene, sequence analysis of the pheS gene, which has previously been proven to be a robust phylogenetic marker for lactic acid bacteria (Naser et al., 2005, 2007), was performed. As published primers did not result in any PCR products, two new primers were designed on the basis of an alignment of available pheS genes from other lactobacilli: phe_forward, 5'-CASGATACSTTCTACATYAC-3' and phe_reverse, 5'-ACCATACCRGCACCYARMACTTC-3'. Annealing temperature was optimal at $54{ }^{\circ} \mathrm{C}$. A $361 \mathrm{bp}$ amplicon of pheS of strain TMW $1.1424^{\mathrm{T}}$ was sequenced (EMBL accession number FN185733). Phylogenetic neighbourhood trees of both genes ( $t u f$ and $p h e S)$ confirmed the position of strain TMW $1.1424^{\mathrm{T}}$ determined using the $16 \mathrm{~S}$ rRNA gene sequence.

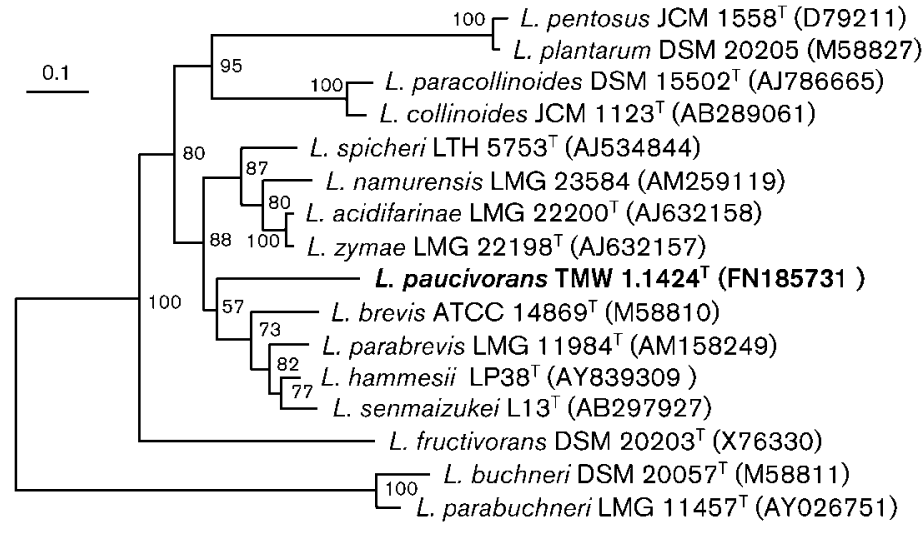

${ }^{100}$ L. pentosus JCM 1558 ${ }^{\top}$ (D79211)

L. plantarum DSM 20205 (M58827)
Fig. 1. Neighbour-joining tree derived from $16 \mathrm{~S}$ rRNA gene sequence analysis showing the relationship of the novel strain TMW $1.1424^{\top}$ to related members of the genus Lactobacillus. The L. buchnerilL. parabuchneri clade was used as an outgroup. Approximately $1500 \mathrm{nt}$ from each sequence was used for alignment. Bar, $1 \%$ estimated sequence divergence. Numbers indicate bootstrap values greater than $50 \%$ (percentage of 100 replications). 

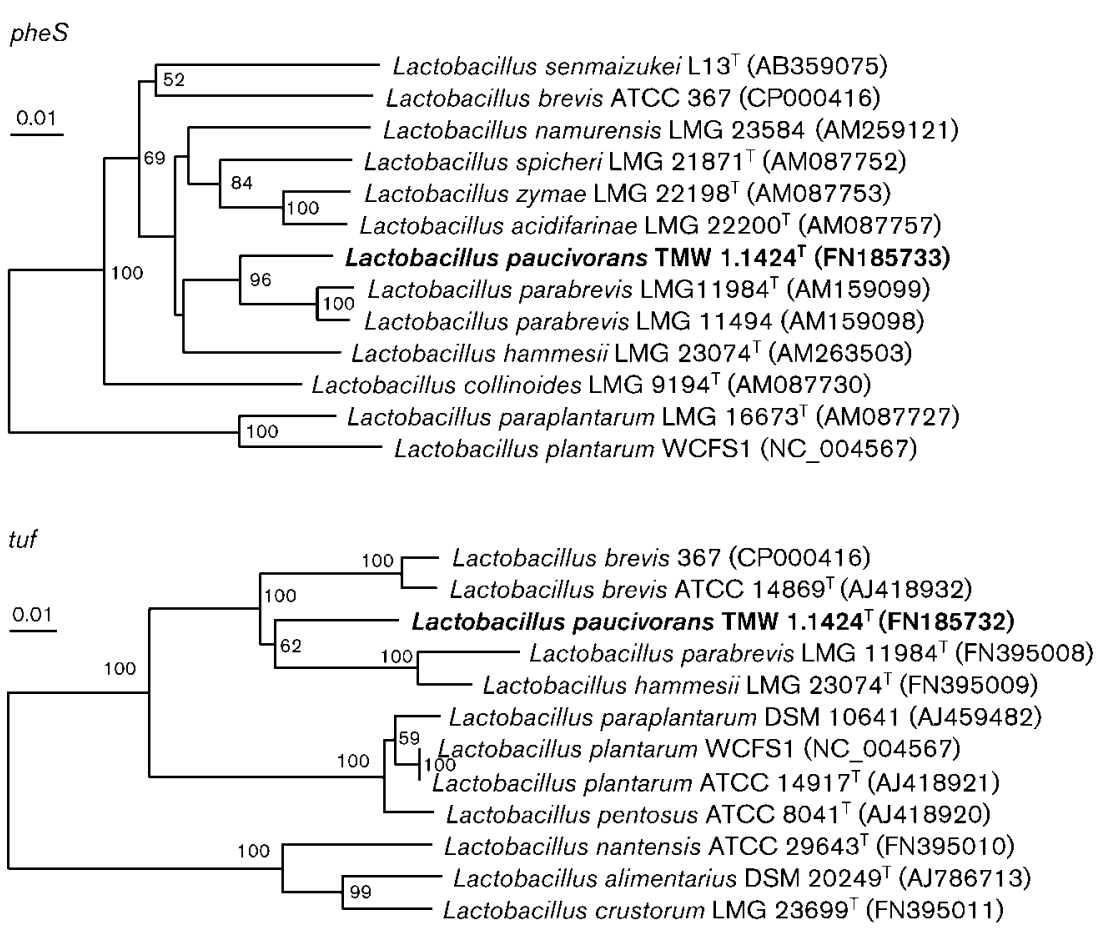

Fig. 2. Neighbour-joining trees obtained with partial protein-encoding sequences of the pheS and tuf genes, showing the relationship of strain TMW $1.1424^{\top}$ with closely related species. Bars, $1 \%$ estimated sequence divergence. Numbers indicate bootstrap values $>50 \%$ (percentage of 100 replications).
These trees revealed a clear affiliation of the novel strain to the genus Lactobacillus, as it was positioned as a separate branch close to L. parabrevis LMG $11984^{\mathrm{T}}$ and L. hammesii DSM $16381^{\mathrm{T}}$.

pheS gene sequence similarities to $L$. parabrevis and $L$. hammesii are 91 and $86 \%$, respectively. These interspecies gap values correspond well to data previously reported by Naser et al. (2007) who determined values that in most cases exceeded $10 \%$ divergence in lactobacilli.

Phylogenetic trees were also reconstructed according to two additional methods, a maximum-likelihood analysis and the maximum-parsimony method (Supplementary Figs S1 and S2, available in IJSEM Online). Whereas branching position of strain TMW $1.424^{\mathrm{T}}$ is stable with the maximum-parsimony algorithm, the topology with maximum-likelihood is markedly different from that based on the $16 \mathrm{~S}$ rRNA gene sequence. However, the independent phylogenetic position of the strain remains.

\section{Chemotaxonomy}

The DNA G + C content was determined by HPLC analyses by the Deutsche Sammlung von Mikroorganismen und Zellkulturen (DSMZ, Braunschweig, Germany) following the protocol previously described by Tamaoka \& Komagata (1984). The DNA G $+\mathrm{C}$ value $(\mathrm{mol} \%)$ was calculated according to Mesbah et al. (1989). The DNA G+C content of strain TMW $1.1424^{\mathrm{T}}$ is $46.6 \mathrm{~mol} \%$.

The presence/absence of meso-diaminopimelic acid (mDAP) in the cell wall peptidoglycan was determined by thin layer chromatography after total hydrolysis (6 M
$\mathrm{HCl}, 16 \mathrm{~h}, 100{ }^{\circ} \mathrm{C}$ ) of whole-cell proteins following the procedure described by Marconi et al. (2000). mDAP was not detected in strain TMW $1.1424^{\mathrm{T}}$.

DNA relatedness values were determined by using chromosomal DNA of strain TMW $1.1424^{\mathrm{T}}$ and its closest neighbours in the 16S rRNA gene sequence tree, $L$. brevis, $L$. parabrevis and L. hammesii. Renaturation kinetics were performed by the DSMZ after the protocol of De Ley et al. (1970) with modifications described by Huß et al. (1983). All experiments were performed in duplicate. Genomic DNADNA relatedness to L. brevis DSM $20054^{\mathrm{T}}$, L. parabrevis LMG $11984^{\mathrm{T}}$ and L. hammesii DSM $16381^{\mathrm{T}}$ was 52.8, 49.6 and $46.2 \%$, respectively. These values are significantly below the $70 \%$ threshold repeatedly recommended as the boundary value for isolates allocated to the same species (RossellóMora \& Amann, 2001; Stackebrandt \& Goebel, 1994; Wayne et al., 1987).

Overall, the results of the present study show that the novel isolate constitutes a distinct branch and does not display a close relationship below the species level with any recognized organism. Moreover, the novel isolate could be distinguished from its close phylogenetic relatives on the basis of phenotypic characteristics. Therefore, based on both phylogenetic and phenotypic criteria, it is evident that the new isolate merits classification as a novel species of the genus Lactobacillus, for which the name Lactobacillus paucivorans sp. nov. is proposed.

\section{Description of Lactobacillus paucivorans sp. nov.}

Lactobacillus paucivorans (pau.ci'vo.rans. L. adj. paucus little; L. part. adj. vorans devouring; N.L. part. adj. paucivorans 
devouring few substrates, relating to the observation that the organism utilizes few carbohydrates).

Cells are Gram-stain-positive, catalase-negative, nonspore-forming and non-motile rods $(1.5-5 \mu \mathrm{m}$ in length and $0.9 \mu \mathrm{m}$ wide), occurring singly, in pairs or in short chains. After $48 \mathrm{~h}$, colonies are approximately $1-2 \mathrm{~mm}$ in diameter, whitish, circular, convex, smooth-edged or roughly textured with fringed edges. Grows at $15{ }^{\circ} \mathrm{C}$, but not at $45{ }^{\circ} \mathrm{C}$. Grows at $5 \% \mathrm{NaCl}$ but not at $10 \% \mathrm{NaCl}$. Grows anaerobically and produces DL-lactic acid. Glucose is not fermented. Fructose is fermented without gas production. Gluconate is not fermented. Produces acid from D-fructose, D-ribose and D-xylose. Weak acid production is observable after $48 \mathrm{~h}$ from melezitose, $\beta$ gentiobiose and D-tagatose. No acid is produced from D- and L-arabinose, D- and L-arabitol, gluconate, $\mathrm{N}$-acetylglucosamine, D-glucose, maltose, methyl $\beta$-xyloside, adonitol, amygdalin, arbutin, cellobiose, dulcitol, aesculin, erythritol, D- and L-fucose, 2- and 5-ketogluconate, glycerol, glycogen, inositol, inulin, D-lyxose, mannitol, D-mannose, methyl $\alpha$ D-mannoside, melibiose, raffinose, rhamnose, sucrose, salicin, starch, sorbitol, L-sorbose, trehalose, turanose, xylitol, L-xylose, galactose, methyl $\alpha$-D-glucoside or lactose. Arginine is not deaminated. The cell wall does not contain meso-diaminopimelic acid. The G $+\mathrm{C}$ content of DNA of the type strain is $46.4 \mathrm{~mol} \%$.

The type strain, TMW $1.1424^{\mathrm{T}}\left(=\mathrm{DSM} 22467^{\mathrm{T}}=\mathrm{LMG}\right.$ $25291^{\mathrm{T}}$ ) was isolated from a storage tank of a brewery.

\section{References}

Back, W. (2005). Brewery. In Colour Atlas and Handbook of Beverage Biology, pp. 10-112. Edited by W. Back. Nürnberg: Verlag Hans Carl.

Behr, J. \& Vogel, R. F. (2009). Mechanisms of hop inhibition: hop ionophores. J Agric Food Chem 57, 6074-6081.

Bohak, I., Thelen, K. \& Beimfohr, C. (2006). Description of Lactobacillus backi sp. nov., an obligate beer-spoiling bacterium. Monatsschr Brauwiss 59, 78-82.

Bover-Cid, S. \& Holzapfel, W. H. (1999). Improved screening procedure for biogenic amine production by lactic acid bacteria. Int J Food Microbiol 53, 33-41.

De Ley, J., Cattoir, H. \& Reynaerts, A. (1970). The quantitative measurement of DNA hybridization from renaturation rates. Eur $J$ Biochem 12, 133-142.

Fujii, T., Nakashima, K. \& Hayashi, N. (2005). Random amplified polymorphic DNA-PCR based cloning of markers to identify the beer-spoilage strains of Lactobacillus brevis, Pediococcus damnosus, Lactobacillus collinoides and Lactobacillus coryniformis. J Appl Microbiol 98, 1209-1220.

Hayashi, N., Ito, M., Horiike, S. \& Taguchi, H. (2001). Molecular cloning of a putative divalent-cation transporter gene as a new genetic marker for the identification of Lactobacillus brevis strains capable of growing in beer. Appl Microbiol Biotechnol 55, 596-603.

Huß, V. A. R., Festl, H. \& Schleifer, K. H. (1983). Studies on the spectrophotometric determination of DNA hybridization from renaturation rates. Syst Appl Microbiol 4, 184-192. lijima, K., Suzuki, K., Ozaki, K. \& Yamashita, H. (2006). horC confers beer-spoilage ability on hop-sensitive Lactobacillus brevis $\mathrm{ABBC} 45^{\mathrm{cc}}$. J Appl Microbiol 100, 1282-1288.

Korakli, M., Schwarz, E., Wolf, G. \& Hammes, W. P. (2000). Production of mannitol by Lactobacillus sanfranciscensis. Adv Food Sci 22, 1-4.

Lathe, W. C., III \& Bork, P. (2001). Evolution of tuf genes: ancient duplication, differential loss and gene conversion. FEBS Lett 502, 113116.

Marconi, E., Sorrentino, E., Mastrocola, L. \& Coppola, R. (2000). Rapid detection of meso-diaminopimelic acid in lactic acid bacteria by microwave cell wall hydrolysis. J Agric Food Chem 48, 3348-3351.

Mesbah, M., Premachandran, U. \& Whitman, W. B. (1989). Precise measurement of the $\mathrm{G}+\mathrm{C}$ content of deoxyribonucleic acid by highperformance liquid chromatography. Int J Syst Bacteriol 39, 159-167.

Naser, S. M., Thompson, F. L., Hoste, B., Gevers, D., Dawyndt, P., Vancanneyt, M. \& Swings, J. (2005). Application of multilocus sequence analysis (MLSA) for rapid identification of Enterococcus species based on rpoA and pheS genes. Microbiology 151, 2141-2150.

Naser, S. M., Dawyndt, P., Hoste, B., Gevers, D., Vandemeulebroecke, K., Cleenwerck, I., Vancanneyt, M. \& Swings, J. (2007). Identification of lactobacilli by pheS and rpoA gene sequence analyses. Int J Syst Evol Microbiol 57, 2777-2789.

Priest, F. G. (1996). Gram-positive brewery bacteria. In Brewing Microbiology, 2nd edn, pp. 127-161. Edited by F. G. Priest \& I. Cambell. London: Chapman \& Hall.

Rosselló-Mora, R. \& Amann, R. (2001). The species concept for prokaryotes. FEMS Microbiol Rev 25, 39-67.

Saitou, N. \& Nei, M. (1987). The neighbor-joining method: a new method for reconstructing phylogenetic trees. Mol Biol Evol 4, 406-425.

Sakamoto, K., Margolles, A., van Veen, H. W. \& Konings, W. N. (2001). Hop resistance in the beer spoilage bacterium Lactobacillus brevis is mediated by the ATP-binding cassette multidrug transporter HorA. J Bacteriol 183, 5371-5375.

Simpson, W. J. \& Fernandez, J. L. (1992). Selection of beer-spoiling lactic acid bacteria and induction of their ability to grow in beer. Lett Appl Microbiol 14, 13-16.

Stackebrandt, E. \& Ebers, J. (2006). Taxonomic parameters revisited: tarnished gold standards. Microbiol Today 33, 152-155.

Stackebrandt, E. \& Goebel, B. M. (1994). Taxonomic note: a place for DNA-DNA reassociation and $16 \mathrm{~S}$ rRNA sequence analysis in the present species definition in bacteriology. Int J Syst Bacteriol 44, 846-849.

Suzuki, K., lijima, K., Sakamoto, K., Sami, M. \& Yamashita, H. (2006). A review of hop resistance in beer spoilage lactic acid bacteria. J Inst Brew 112, 173-191.

Tamaoka, J. \& Komagata, K. (1984). Determination of DNA base composition by reversed-phase high-performance liquid chromatography. FEMS Microbiol Lett 25, 125-128.

Valcheva, R., Korakli, M., Onno, B., Prévost, H., Ivanova, I., Ehrmann, M. A., Dousset, X., Gänzle, M. G. \& Vogel, R. F. (2005). Lactobacillus hammesii sp. nov., isolated from French sourdough. Int J Syst Evol Microbiol 55, 763-767.

Vancanneyt, M., Naser, S. M., Engelbeen, K., De Wachter, M., Van der Meulen, R., Cleenwerk, I., Hoste, B., De Vuyst, L. \& Swings, J. (2006). Reclassification of Lactobacillus brevis strains LMG 11494 and LMG 11984 as Lactobacillus parabrevis sp. nov. Int J Syst Evol Microbiol 56, 1553-1557.

Wayne, L. G., Brenner, D. J., Colwell, R. R., Grimont, P. A. D., Kandler, O., Krichevsky, M. I., Moore, L. H., Moore, W. E. C., Murray, R. G. E. \& other authors (1987). International Committee on Systematic Bacteriology. Report of the ad hoc committee on reconciliation of approaches to bacterial systematics. Int J Syst Bacteriol 37, 463-464. 